\title{
$\mathrm{Ta}$ 함량에 따른 $\mathrm{Ti}-\mathrm{xTa}$ 합금의 부식특성
}

\author{
김 현 주·최 한 철 \\ 조선대학교 치의학전문대학원 치과재료학교실 및 생체재료나노계면활성화센터 \\ (2012년 12월 10일 접수, 2013년 02월 27일 수정, 2013년 02월 27일 채택)
}

\section{Corrosion Characteristics of Ti-xTa Alloys with Ta contents}

\author{
H. J. Kim and H. C. Choe ${ }^{\dagger}$ \\ Department of Dental Materials \& Research Center of Nano-Interface Activation for Biomaterials, School of Dentistry, Chosun University, \\ Gwangju 501-759, Korea
}

(Received December 10, 2012; Revised February 27, 2013; Accepted February 27, 2013)

\begin{abstract}
The purpose of this study was to investigate corrosion characteristics of Ti-xTa alloys with Ta contents. Ti-xTa alloys used as samples $(\mathrm{x}=30,40 \%)$ were arc-melted under argon atmosphere of $99.9 \%$ purity. Ti-xTa alloys were homogenized for $12 \mathrm{hr}$ at $1000^{\circ} \mathrm{C}$ and then water quenched. The surface characteristics of Ti-xTa alloys were investigated using optical microscopy (OM) and X-ray diffractometer (XRD). The anodic corrosion behaviors of the specimens were examined through potentiodynamic, potentiostatic and galvanostatic test in $0.9 \% \mathrm{NaCl}$ solution at $36.5 \pm 1^{\circ} \mathrm{C}$. After corrosion test, the surface characteristics of Ti-xTa alloys were investigated using OM. The microstructure of Ti-Ta alloy showed the beta structure with Ta content. The corrosion resistance of $\mathrm{Ti}$ alloy was improved by increasing Ta content and the corrosion morphology of Ti-Ta alloy showed that the site attacked by chloride ion decreased from the active to passive region with Ta content. Potential of Ti-40Ta alloy increased as time increased, whereas, current density of Ti-40Ta alloy decreased as time increased compared to Ti-30 alloy.
\end{abstract}

Keywords : Ti-Ta alloy, Ta content, potentiodynamic, potentiostatic, galvanostatic, biomaterial

\section{1. 서 론}

생체재료로 사용되는 $\mathrm{Ti}$ 합금은 독성이나 발암성이 없고 부작용이나 인체 거부반응이 없는 생체적합성이 우수해야 하고 인장강도, 탄성률, 내마모성, 피로강도 등 기계적 성질 이 양호해야 하며 인체 내의 혹독한 부식 환경을 견딜 수 있는 강력한 내식성을 갖추어야 한다. ${ }^{1,2)}$

현재 생체용 금속재료로 많이 쓰이는 재료는 상용화된 순수 타이타늄 $(\mathrm{Cp}-\mathrm{Ti})$ 과 $\mathrm{Ti}-6 \mathrm{Al}-4 \mathrm{~V}$ 합금 등이 있으며 순수 $\mathrm{Cp}-\mathrm{Ti}$ 는 산화막의 형성으로 금속 이온이 용출되지 않으므로 생체 내에서 내식성이 높고 응력부식균열을 거의 일으키지 않는 장점이 있다. 그러나 고관절이나 임플란트로 사용 시 마모가 심하고 강도가 낮아 파손되는 경우가 있다. ${ }^{3)}$ 따라서 $\mathrm{Ti}-6 \mathrm{Al}-4 \mathrm{~V}$ 합금을 사용하는데 이 합금의 구성 원 소인 알루미늄(aluminium, $\mathrm{Al}$ )이 알츠하이머를 유발하고 바나듬 (vanadium, V)이 세포독성을 유발될 수 있다고 보 고되었다. ${ }^{4-7)}$ 따라서 최근 이러한 문제점을 개선하기 위하

\footnotetext{
${ }^{\dagger}$ Corresponding author: hcchoe@chosun.ac.kr
}

여 $\mathrm{Al}$ 과 $\mathrm{V}$ 이 포함되지 않고, 무독성인 $\mathrm{Ta}, \mathrm{Nb}, \mathrm{Zr}, \mathrm{Hf}$ 과 같은 원소를 $\mathrm{Ti}$ 에 첨가하여 기계적 성질과 생체적합성이 우수한 $\mathrm{Ti}$ 합금에 대한 연구개발의 필요성이 크게 증가하고 있다. ${ }^{8)}$ 뿐만 아니라, $\mathrm{Ti}$ 합금이 생체 내에 매식되었을 경우 골과 합금간의 탄성계수의 차이로 인하여 응력차폐현상 (stress shielding)이 발생하여 인접한 골에 높은 응력이 전달되므로 생체적합도가 감소하여 임상적으로 문제가 되 고 있다. ${ }^{9-11)}$

이러한 $\mathrm{Ti}-6 \mathrm{Al}-4 \mathrm{~V}$ 의 임상적인 문제점 때문에 이를 개 선하기 위하여 탄성계수가 골과 유사한 조건을 갖도록 $\mathrm{Ta}$ 과 같은 $\beta$ 형 안정화 원소를 첨가하여 제조한 $\beta$ 형 $\mathrm{Ti}$ 합금 개발에 대한 관심이 증가하고 있다. $\beta$ 형 $\mathrm{Ti}$ 합금은 $\mathrm{Ti}-\mathrm{Ta}$ 을 들 수 있는데 $\mathrm{Ta}$ 을 $30 \mathrm{wt} \%$ 까지 첨가하면 탄성계수가 크게 감소하고 강도는 크게 증가시킬 수 있다는 보고가 있 다. ${ }^{12-14)} \mathrm{Ta}$ 은 $\beta$ 안정화 원소로써 $\mathrm{Ti}$ 합금의 탄성계수를 감 소시킴과 동시에 세포독성을 일으키지 않는 등 생체적합성 이 우수하다.

따라서 본 연구에서는 저탄성계수를 갖는 $\beta$ 형 $\mathrm{Ti}$ 합금인 $\mathrm{Ti}-\mathrm{Ta}$ 합금을 제조하여 균질화 처리한 후 표면의 조직을 
알아보고, Ta함량에 따른 $\mathrm{Ti}-\mathrm{xTa}$ 합금의 부식특성을 알아 보기 위하여 전기화학적인 방법으로 조사하였다.

\section{2. 실험재료 및 방법}

\section{1 합금제조}

본 실험에서 $\operatorname{Ti}-\mathrm{xTa}(\mathrm{x}=30,40)$ 합금을 제조하기 위해 $\mathrm{Ti}$ (G\&S TITANIUM, Grade. 4, USA) 와 펠렛 (pellet) 형태의 Ta (Kurt J. Lesker company, 99.95\% pure, USA)을 사용하였다. Ti-xTa 합금은 진공 아크 용해로를 이용하여 제조하였으며, Ti에 Ta을 30 및 $40 \mathrm{wt} \%$ 칭량하 였다. 제조과정에서 증발되는 합금의 양은 보정하여 제조하 였으며, 제조된 합금은 $\mathrm{EDX}$ (energy dispersive $\mathrm{x}$-ray spectroscopy) 분석한 결과, 제조된 합금의 성분이 각각 검 출되어 합금이 잘 이루어 졌다. $10^{-3} \mathrm{Torr}$ 의 진공분위기에 서 정제된 아르곤 가스를 충전하고 다시 진공을 유지하였으 며, 챔버 내에 존재하는 산화를 최소화하기 위해 시료를 용 해하기 전에 스폰지 상 $\mathrm{Ti}$ 를 용해하여 잔존하는 산소량을 제거 하였다. Arc Melting은 20번 반복 용해하여 실험을 수행하였으며, 제조된 시편은 전기로 (Model MSTF1650, $\mathrm{JAPAN}$ )를 이용하여 $\mathrm{Ar}$ 상태 내에서 $1000^{\circ} \mathrm{C} 12$ 시간 동안 균질화 처리하였다.

\section{2 합금의 미세조직 관찰}

미세조직 관찰을 위해 고속 다이아몬드 정밀절단기를 이 용하여 직경이 $10 \mathrm{~mm}$, 두께가 $2.5 \mathrm{~mm}$ 기 되도록 절단한 후, 2,000 grit의 $\mathrm{SiC}$ 연마지까지 단계적으로 습식 연마하고 최종적으로 $0.3 \mu \mathrm{m}$ 알루미나 분말로 미세연마 한 후 초음 파 세척을 하였다. 준비한 시편은 $2 \mathrm{ml} \mathrm{HF}+3 \mathrm{ml} \mathrm{HNO}_{3}$ $+5 \mathrm{ml} \mathrm{HCl}+20 \mathrm{ml}$ 증류수의 Killer's 용액으로 에칭한 후 광학현미경을 이용하여 조직을 관찰하였으며, 결정구조 는 XRD (X-ray diffractometer)을 사용하였다.

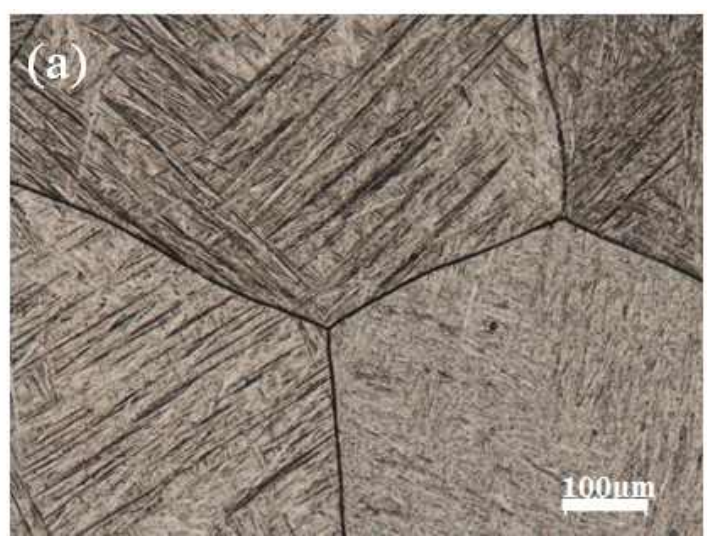

Fig. 1. OM images showing the microstructures of the Ti-xTa;

\section{3 부식실험}

생체용 $\mathrm{Ti}-\mathrm{xTa}(\mathrm{x}=30,40)$ 합금의 부식특성을 알아보 기 위해 전기화학적인 방법(Model 263A, EG\&G, USA)을 이용하였으며, 실험용액으로는 $36.5 \pm 1{ }^{\circ} \mathrm{C}$ 의 $0.9 \% \mathrm{NaCl}$ 전해액을 사용하였으며, 탈기된 분위기를 유지하기 위해 아 르곤가스를 $5 \mathrm{sccm}$ 으로 일정하게 흘려주었다. 작업전극 (working electrode)에는 시편을 기준 전극(reference electrode)은 포화감홍전극(saturated calomel electrode, $\mathrm{SCE}$ )을 상대전극(counter electrode) 으로는 고밀 도 탄소전극을 사용하였으며, 동전위분극 시험은 정전위차 계를 이용하여 $-1500 \mathrm{mV}$ 에서 $+2000 \mathrm{mV}$ 까지 순방향 주 사를 하였으며 주사속도는 $1.667 \mathrm{mV} / \mathrm{min}$ 으로 하였다. 각 각 활성태 및 부동태구간에서 시편을 꺼내어 표면의 부식상 태를 단계별로 조사 하였다. 시편 표면의 안정성을 조사하 기 위하여 정전위방법으로 $+300 \mathrm{mV}(\mathrm{SCE})$ 의 일정 전위에 서 전류밀도-시간과 정전류방법으로 부동태전류밀도 구간 인 $3.8 \mu \mathrm{A} / \mathrm{cm}^{2}$ 에서 전위-시간의 곡선도 조사하였다. 표 1은 부식실험 조건을 나타내고 있다.

Table 1. The experimental conditions

\begin{tabular}{cc}
\hline & Potentiodynamic test \\
\hline Working Equipment & EG\&G Co, Model-263 A \\
Working Electrode & Samples (Ti-xTa) \\
Reference Electrode & Saturated Calomel Electrode \\
Counter Electrode & High Dense Carbon \\
Electrolyte & $0.9 \% \mathrm{NaCl}$ \\
Working Temp. & $36.5 \pm 1^{\circ} \mathrm{C}$ \\
Gas Purging & $\mathrm{Ar}$ gas, $5 \mathrm{sccm}$ \\
Scan rate & $1.667 \mathrm{mV} / \mathrm{s}$ \\
Scan Definition & $-1500 \sim+2000 \mathrm{mV}$ \\
\hline
\end{tabular}

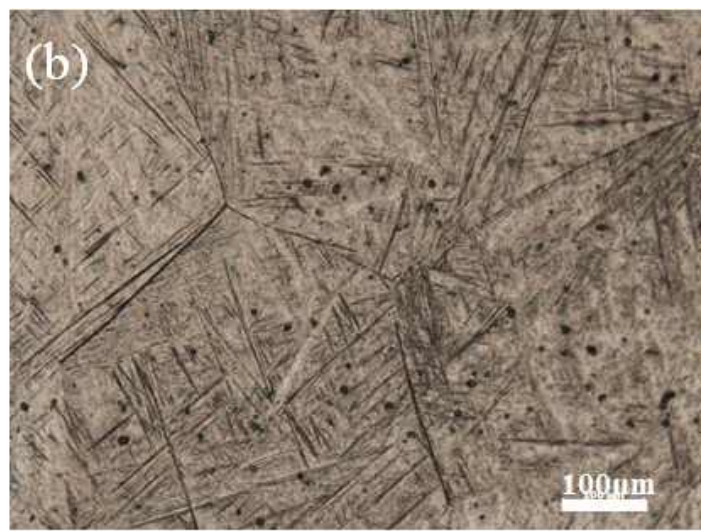

(a) Ti-30Ta, (b) Ti-40Ta. 


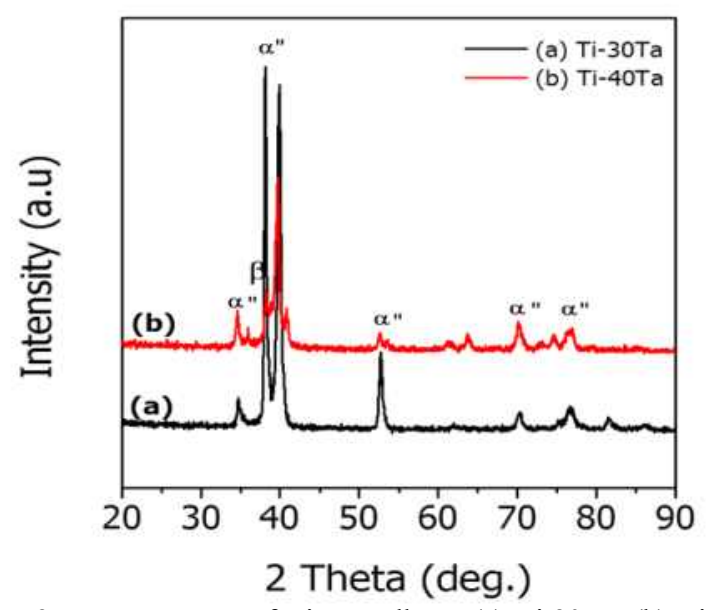

Fig. 2. XRD patterns of Ti-xTa alloys: (a) Ti-30Ta, (b) Ti-40Ta.

\section{3. 결과 및 고찰}

그림 1 은 $\mathrm{Ti}-\mathrm{Ta}$ 이원계 합금을 $\beta$ 변태점 보다 약 $100^{\circ} \mathrm{C}$ 정도 높은 $1000^{\circ} \mathrm{C}$ 에서 12 시간동안 균질화 처리한 후 광학 현미경을 이용하여 미세조직을 관찰한 사진이다. Ti-Ta상 태도에서 알 수 있듯이 $\beta$ 변태점 이상의 온도에서 균질화 처리한 $\mathrm{Ti}-\mathrm{Ta}$ 합금의 미세조직은 $\beta$ 로부터 $\alpha$ 상의 핵생성 과 성장이 일어나서 widmanstatten 조직을 가지는 $\alpha+\beta$ 평형상을 가지게 된다. Ta함량이 증가할수록 백색의 $\beta$ 상 은 등축정 구조를 갖게 되며 조대화된 것을 관찰하였고, 층 상구조의 $\alpha$ 상은 점차적으로 침상으로 변화되었고 미세화 되는 것을 볼 수 있었다. 특히 $40 \mathrm{wt} \% \mathrm{Ta}$ 이 첨가된 합금의 미세조직을 광학현미경으로 관찰한 결과 등축정 $\beta$ 단상이 나타난 것을 알 수 있었다. ${ }^{15)}$ 균질화 처리한 $\mathrm{Ti}-\mathrm{Ta}$ 합금의

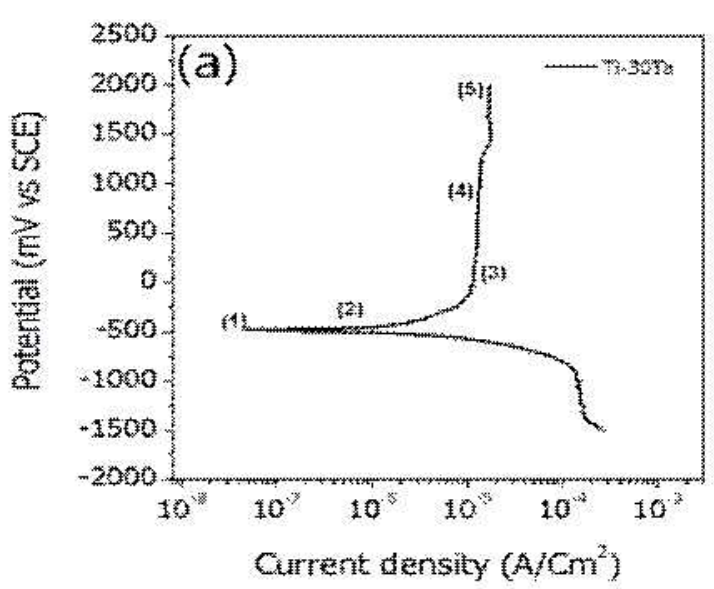

미세조직을 관찰한 결과 $\mathrm{Ta}$ 함량에 따라 침상의 $\alpha$ 상 조직 이 나타나고 $\beta$ 상의 부피 분율도 상대적으로 증가함을 알 수 있었다. 일반적으로 $\mathrm{Ti}$ 합금의 미세조직 상에서 침상인 $\alpha$ 상의 크기와 폭, $\alpha$ 상과 $\beta$ 상의 부피분율은 재료의 강도 와 연성등 물성에 영향을 미치며, 침상 $\alpha$ 상의 크기가 작을 수록 인장강도와 피로특성이 우수하고, $\beta$ 상이 $\alpha$ 결정립 계 면에서 void의 형성에 의한 파괴를 저지하여 creep강도, 파괴인성을 향상 시키는 조직으로 알려져 있다.

그림 2는 균질화 처리된 $\mathrm{Ti}-\mathrm{Ta}$ 합금의 $\mathrm{X}$-선 회절 피크 를 나타낸 것으로 $\beta$ 상 피크와 $\alpha$ 상 피크가 검출되었으며 $\mathrm{Ta}$ 함량이 증가함에 따라 $\beta$ 상 피크가 증가하고 있다는 것 도 확인할 수 있었다. 이와 같이 $\mathrm{Ta}$ 첨가에 따른 $\beta$ 상의 증가 는 Ta이 Ti의 $\beta$ 상 안정화 원소이기 때문이며 이러한 결과 는 미세조직에서 고찰한 것과 일치하는 경향을 나타내었다.

그림 3 은 이원계 $\mathrm{Ti}-\mathrm{Ta}$ 합금을 제조하여 균질화처리후 $\mathrm{Ta}$ 함량에 따른 전기화학적 특성을 $36.5 \pm 1{ }^{\circ} \mathrm{C}$ 의 $0.9 \%$ $\mathrm{NaCl}$ 용액에서 조사하기위하여 얻어진 양극분극곡선이다. 그래프에서 알 수 있듯이 1 번 구간까지 환원반응이 일어나 며, 2 번 구간 이후부터 산화반응이 시작하였고, 3 번 이후부 터는 부동태 영역을 나타내고 있다. 활성태영역에서는 전류 밀도가 크게 증가하다가 활성태 영역을 지난 후 부동태피막 이 형성되는 영역에서는 전류밀도가 일정하게 유지됨을 보 이는데 이는 안정한 $\mathrm{TiO}_{2}$ 와 $\mathrm{Ta}_{2} \mathrm{O}_{5}$ 의 산화막이 형성되어 일정한 전류밀도를 유지함을 보이고 있다. 전위가 +1500 $\mathrm{mV}$ 이상 가해져도 부동태피막의 파괴가 나타나지 않아 매 우 안정한 부동태를 형성하는 것을 관찰할 수 있었다. Ta의 함량이 증가함에 따라 거의 비슷한 분극곡선의 양상을 보이 고 전위가 더 증가하면 부동태전류밀도의 변화가 4 영역이 후에서 $\mathrm{Ti}-40 \mathrm{Ta}$ 에 비하여 $\mathrm{Ti}-30 \mathrm{Ta}$ 의 경우는 다소 불안 정한 형태를 보이지만 높은 전위에서도 일정하게 유지되어

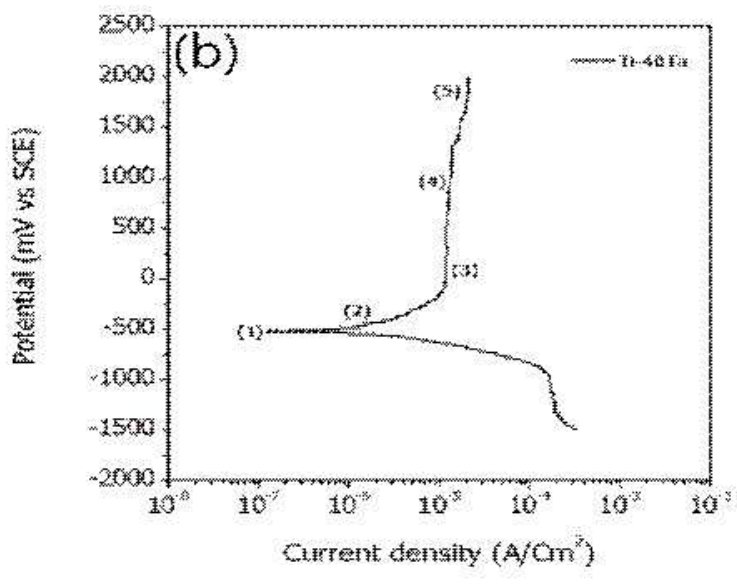

Fig. 3. Anodic polarization curves of Ti-xTa alloys after potentiodynamic test in $0.9 \% \mathrm{NaCl}$ solution at $36.5 \pm 1{ }^{\circ} \mathrm{C}$. (a) $\mathrm{Ti}-30 \mathrm{Ta}$, (b) Ti-40Ta. 
Table 2. Corrosion potential $\left(\mathrm{E}_{\text {corr }}\right)$, current density at $+300 \mathrm{mV}$ $\left(I_{300 \mathrm{mv}}\right)$, and corrosion current density $\left(I_{\text {corr }}\right)$ of Ti-xTa alloys after potentiodynamic test in $0.9 \% \mathrm{NaCl}$ solution at $36.5 \pm 1{ }^{\circ} \mathrm{C}$

\begin{tabular}{ccccc}
\hline Solution & Sample & $\mathbf{E}_{\text {corr }}(\mathrm{mV})$ & $\mathrm{I}_{\mathrm{corr}}\left(\mathrm{mA} / \mathrm{cm}^{2}\right)$ & $\mathrm{I}_{300 \mathrm{mI}}\left(\mathrm{mA} / \mathrm{cm}^{2}\right)$ \\
\cline { 2 - 5 } & $\mathrm{Ti}-30 \mathrm{Ta}$ & -481 & $5.50 \times 10^{-6}$ & $1.22 \times 10^{-5}$ \\
$0.9 \% \mathrm{NaCl}$ & $\mathrm{Ti}-40 \mathrm{Ta}$ & -516 & $4.83 \times 10^{-6}$ & $1.22 \times 10^{-5}$ \\
\hline
\end{tabular}

$\mathrm{Ta}$ 함량이 더욱 안정된 피막의 형성에 기여하였음을 알 수 있다. 이는 앞의 미세조직에서도 알 수 있듯이 $\mathrm{Ti}-40 \mathrm{Ta}$ 은 안정한 베타구조의 조직을 갖음으로써 마르텐사이트 조직 이 다소 많은 $\mathrm{Ti}-30 \mathrm{Ta}$ 보다는 부동태 구간에서 내식성이 우수함을 나타내고 있다.

표 2는 분극실험에서 얻은 부식 데이터를 나타내고 있으 며 $\mathrm{Ti}-30 \mathrm{Ta}$ 과 $\mathrm{Ti}-40 \mathrm{Ta}$ 의 부식전위는 각각 $-481 \mathrm{mV}$ 와 $-516 \mathrm{mV}$ 값을 가지며, $+300 \mathrm{mV}$ 에서의 부식전류밀도는 서 로 유사한 범위에 있지만 전위가 증가함에 따라서 차이가 나게 됨을 알 수 있다.

그림 4 와 5 는 그림 3 의 분극곡선에서 각 부식전위구간, 활성태구간, 및 부동태구간에서 부식형상을 관찰하기 위하 여 광학현미경을 이용하여 부식표면을 관찰한 것으로 그림 4 는 $\mathrm{Ti}-30 \mathrm{Ta}$ 을, 그림 5 는 $\mathrm{Ti}-40 \mathrm{Ta}$ 합금의 것을 각각 나 타내고 있다. 부식후 표면은 표면결함이 활성태영역에서 부 동태영역으로 갈수록 감소됨을 알 수 있는데 즉 활성태영역 에서 발생된 결함이 $\mathrm{TiO}_{2}$ 와 $\mathrm{Ta}_{2} \mathrm{O}_{5}$ 의 부동태 피막의 형성으 로 인하여 현미경상에 감소된 것으로 나타났다. 이는 분극 곡선에서 활성태영역에서 전류밀도가 크게 증가하는 것과 일치하며 활성화된 결함은 합금제조과정에서 발생된 기포
이거나 마르텐사이트 조직이 존재한 부분에서 $\mathrm{Cl}$ 이온에 의해 침식을 집중적으로 받아 핏트가 발생되었다가 부동태 영역으로 전위가 증가함에 따라서 다시 표면에 부동태피막 이 형성되어 결함이 감소한 것으로 생각된다. 또한 2 영역에 서 확대한 그림 그림 4와 5(b-1)에서 보면 침식된 형태임 을 확인할 수 있다. 그러다가 전위가 증가하면 이러한 침식 된 자리가 크게 감소하여 나타남을 알 수 있다. 이는 $\mathrm{Ta}_{2} \mathrm{O}_{5}$ 산화막의 형성으로 $\mathrm{TiO}_{2}$ 산화막보다 더 안정하고 강력한 산화막이 형성되었음을 나타내며 $\mathrm{Ta}$ 함량이 증가할수록 내 식성은 향상된다는 보고와 일치하였고 ${ }^{11)} \mathrm{Ta}$ 이 $\mathrm{Ti}$ 합금에 첨가되면 금속 이온의 방출을 감소시키기 때문이다 ${ }^{11}$. 생체 적합측면에서 $\mathrm{Ti}-\mathrm{Ta}$ 합금의 표면에 생성된 $\mathrm{TiO}_{2}$ 와 $\mathrm{Ta}_{2} \mathrm{O}_{5}$ 산화막은 체액 내에서 비활성이기 때문에 생체적합성도 뛰 어나다고 보고되었다. ${ }^{11}$

그림 6 과 7은 $\mathrm{Ta}$ 함량에 따른 부동태영역의 피막안정성 을 평가하기 위하여 정전위법과 정전류법을 수행하였다. 그 림 6 은 일정한 전위를 유지시켜 주면서 전류밀도와 시간에 따른 내식성을 보여주는 정전위시험곡선을 나타내는 그림 이다. 일정 전위에서 같은 시간을 비교해보면 $\mathrm{Ta}$ 함량이 증 가될 수록 전류밀도 값이 더 낮은 것으로 보아 $\mathrm{Ta}$ 함량이 증가됨으로써 안정된 부동태파막을 형성함으로써 좋은 내 식성을 나타냄을 다시 확인 할 수 있다.

그림 7은 일정한 전류밀도를 유지시켜 주면서 전위와 시 간에 따른 정전류시험곡선을 나타내는 그림이다. 일정 전류 밀도에서 같은 시간을 비교해보면 Ta 함량이 증가됨에 따 라 전위가 증가하는 것으로 보아 안정한 부동태 피막이 형성되었음을 알 수 있어 $\mathrm{Ta}$ 이 첨가됨으로써 내식성을 증 가시킴을 확인 할 수 있다.

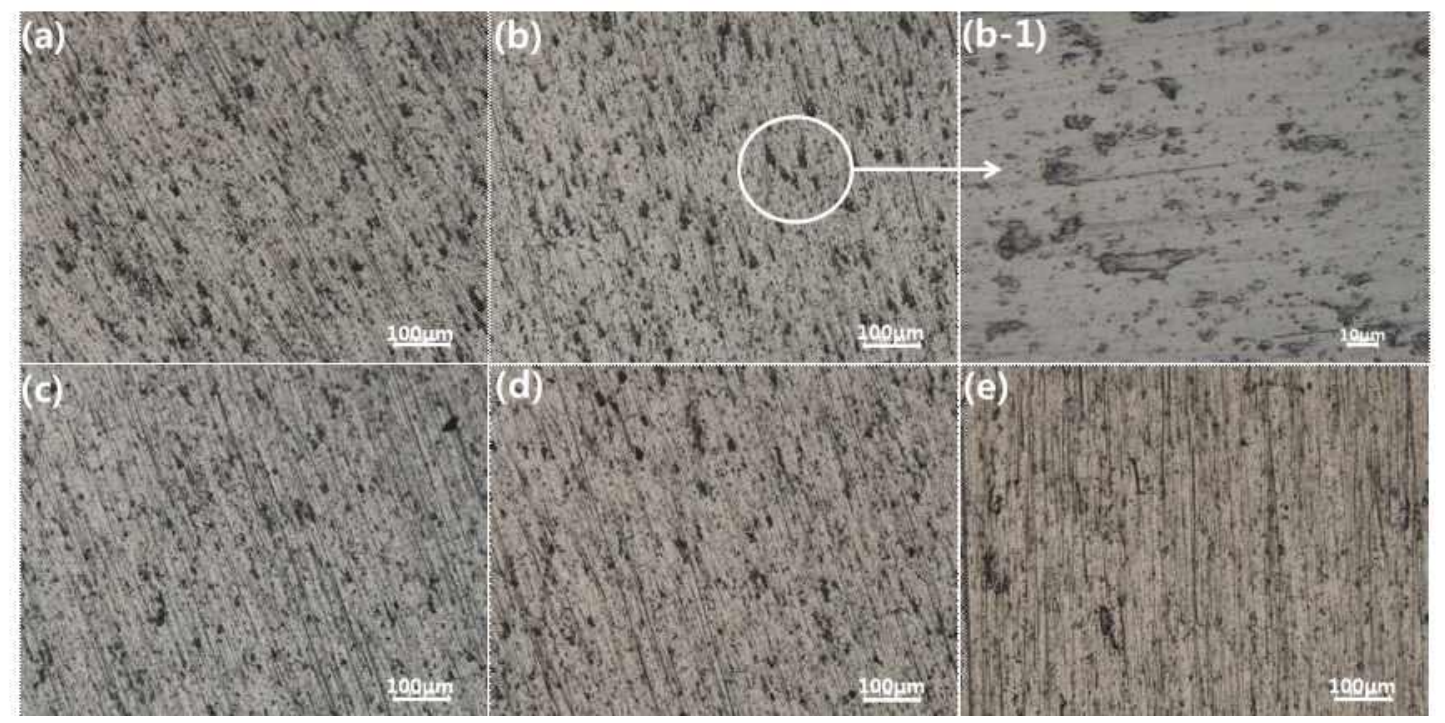

Fig. 4. OM images showing the corrosion morphology of Ti-30Ta after anodic polarization test at (a) 1 region, (b),(b-1) 2 region, (c) 3 region, (d) 4 region, and (e) 5 region of Fig. 3(a). 

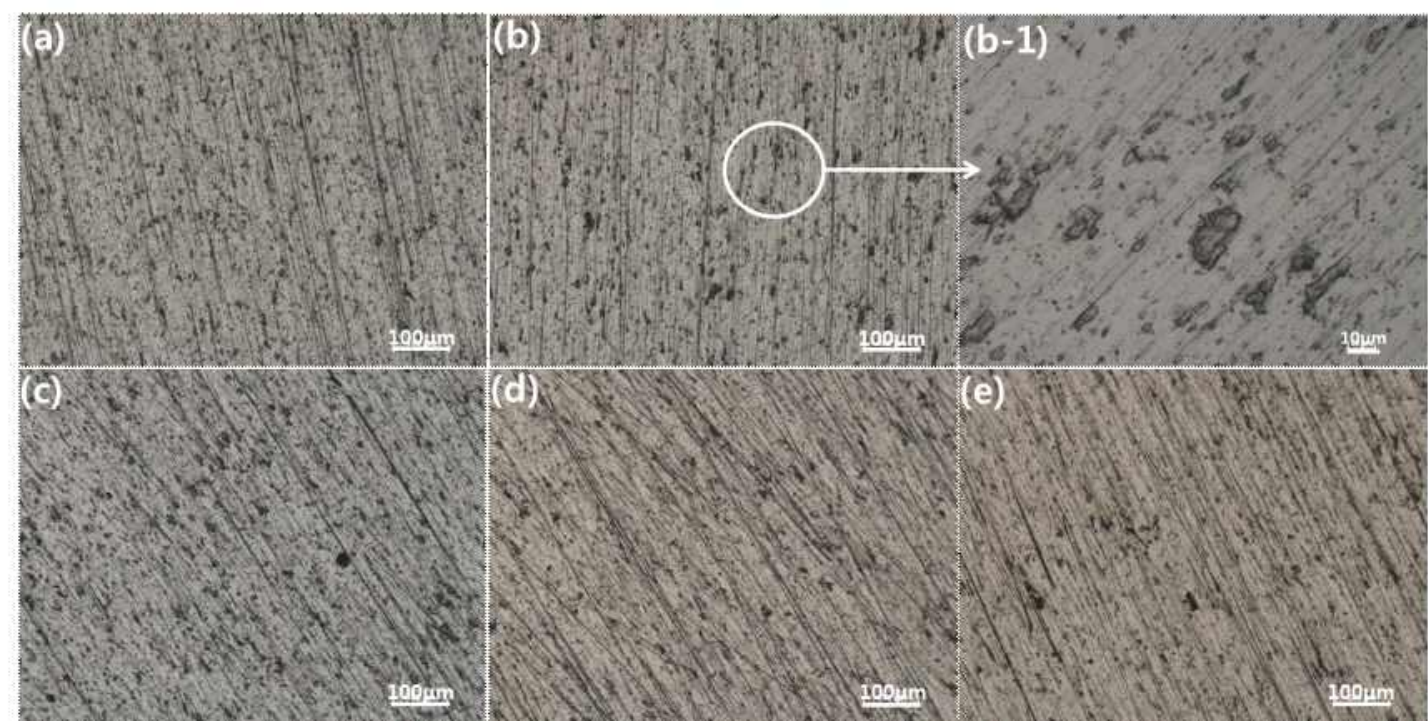

Fig. 5. OM images showing the corrosion morphology of Ti-40Ta after anodic polarization test at (a) 1 region, (b),(b-1) 2 region, (c) 3 region, (d) 4 region, and (e) 5 region of Fig. 3(b).

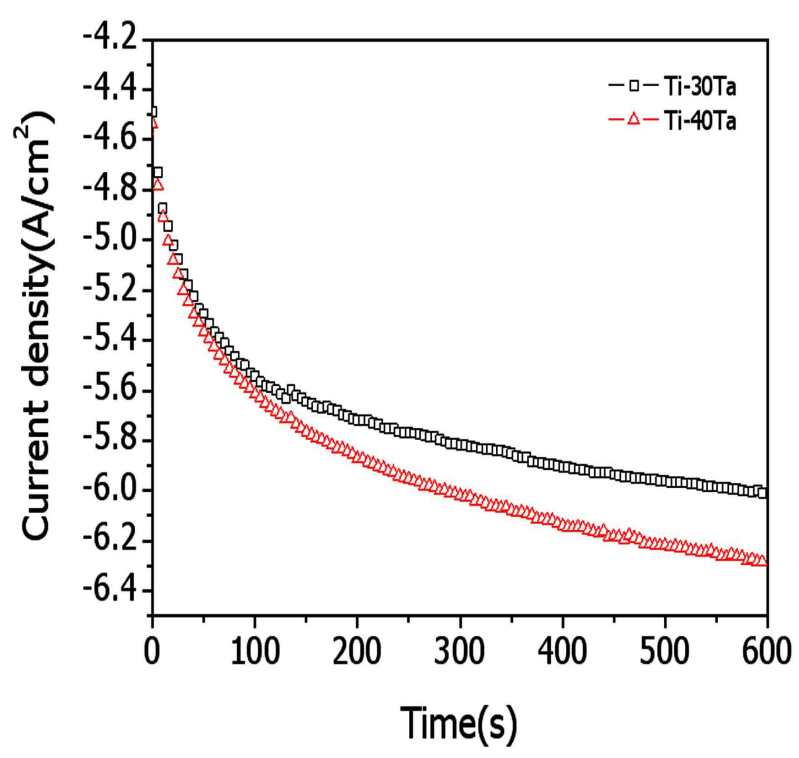

Fig. 6. Current-time curves of Ti-xTa alloys at $+300 \mathrm{mV}$ in $0.9 \% \mathrm{NaCl}$ solution at $36.5 \pm 1{ }^{\circ} \mathrm{C}$.

\section{4. 결 론}

$\mathrm{Ta}$ 함량에 따른 $\mathrm{Ti}-\mathrm{xTa}$ 합금의 부식특성을 조사한 결과 다음과 같은 결론을 얻었다.

1. $\mathrm{Ti}-\mathrm{xTa}$ 합금에서 $\mathrm{Ta}$ 의 함량이 증가할수록 $a$ 상의 조직 이 $\beta$ 상의 미세구조로 변화되었다.

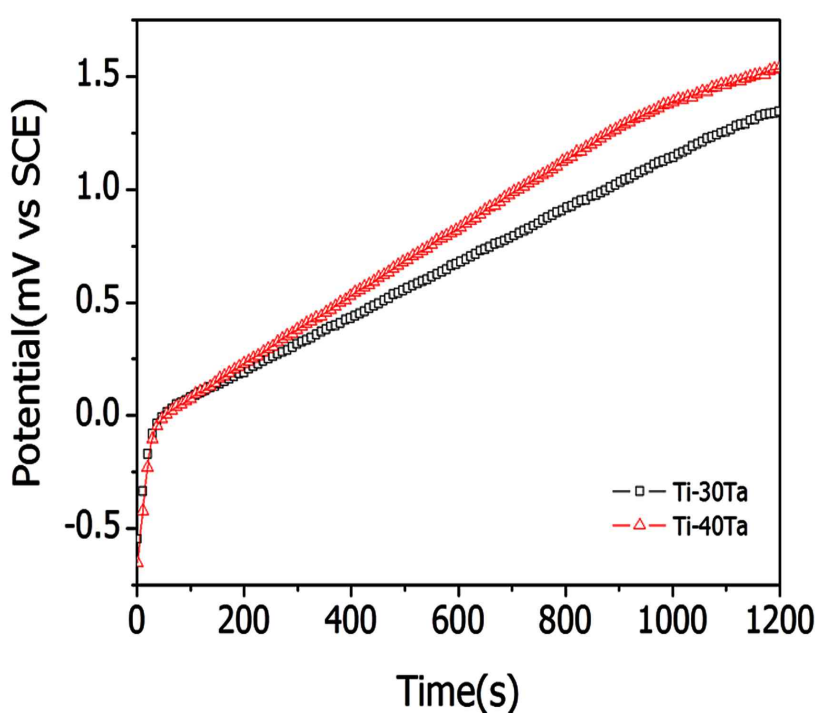

Fig. 7. Potential-time curves of Ti-xTa alloys in $0.9 \% \mathrm{NaCl}$ solution at $36.5 \pm 1{ }^{\circ} \mathrm{C}$.

2. $\mathrm{Ti}-\mathrm{xTa}$ 합금에서 $\mathrm{Ta}$ 의 함량이 증가할수록 부식전위, 부 식전류밀도 및 $+300 \mathrm{mV}$ 에서의 부식 전류밀도차는 거의 없었으나 전위값이 증가할수록 부동태영역에서 전류밀 도의 변화가 일정하였다.

3. $\mathrm{Ti}-\mathrm{xTa}$ 합금에서 $\mathrm{Ta}$ 의 함량이 증가할수록 활성태영역 에서 $\mathrm{Cl}$ 이온에 의해 침식된 자리의 수가 감소하였으며 활성태영역에서 부동태영역으로 갈수록 크게 감소함을 
보였다.

4. $\mathrm{Ti}-\mathrm{xTa}$ 합금에서 $\mathrm{Ta}$ 의 함량이 증가할수록 전류밀도시간곡선에서 전류밀도가 감소하였으며 전위-시간곡선 에서 전위가 증가하였다.

\section{참 고 문 헌}

1. J. Black and G Hastings., Handbook of Biomaterial Properties. Champman \& Hall 135, (1998).

2. F. Andress von Recum., Handbook of biomaterial Evaluation Tayor \& Francis 1, (1999).

3. E. kobayashi, L. K. Gardner, R. W. Toth, J. Prosthetdent, 54, 410 (1985).

4. M. F. Semlitsch, H. Weber, R. M. Streicher, R. Schon, Biomaterials, 13, 781 (1992).

5. Y. Okazaki, S. Rao, S.Asao, T. Tateishi, S. katsuda, Y. Furuki, J. Japan Inst. Metals, 9, 890 (1996).

6. A. K. shukla, R. Balasubramaniam, S. Bhargava, J.
Alloys Comp, 389, 144 (2005).

7. D. Kuroda, M. Niiomi, Mater. Sci. Eng, A 243, 244 (2001).

8. H. C. Choe, Thin solid Film 519, 4652 (2011).

9. Y. L. Zhou, M. Niinomi, T. Akahori, Mater. Sci. Eng, A 384, 92 (2004).

10. Y. L. Zhou, M. Niinomi, T. Akahori, Mater. Sci. Eng, A 371, 283 (2004).

11. Y. L. Zhou, M. Niinomi, T. Akahori, H. fukui, H. Toda, Mater. Sci. Eng, A 398, 28 (2005).

12. S. E. Kim, J. H. Son, Y. T. Hyun, H. W. Jeong, Y. T. Lee, J. S. Song, J. H. Lee, Met. Mater. Int., 13, 151 (2007).

13. S. E. Kim, H. W. Jeong, Y. T. Hyun, Y. T. Lee, C. H. Jung, S. K. Kim, J. S. Song, J. H. Lee, Met. Mater. Int., 13, 145 (2007).

14. Y. L. Zhou, M. Niinomi, Materials Sci. and Eng., A 29, 1061 (2009).

15. D. Mareci, R. Chelariu, D. M.Gordin, G. Ungureanu, T. Gloriant, Acta Biomaterialia, 5, 3625 (2009). 